\title{
Efficacy of some promising plant essential oils to control the red palm weevil Rhynchophorus ferrugineus olivier (coleoptera: curculionidae) under laboratory conditions
}

\author{
Ali M.A. *, K.M. Mohanny, G.S. Mohamed and R.O.H. Allam \\ Plant Protection Department, Faculty of Agriculture, South Valley University, Qena 83523, \\ Egypt
}

\begin{abstract}
Red Palm Weevil is the most dangerous palm pest in Egypt and the Middle East. This study was conducted to evaluate some plants essential oils for use in the control of this pest in egg and larval stages. five individual different oils (orange oil, lemon oil, eucalyptus oil , castor oil, and basil oil)and three mixtures of (chilli+ thyme + lavender $=$ )k1, mixture of (Colocynth and neem $)=\mathrm{k} 2$, and mixture of (Radicchio + turmeric + Silene $)=\mathrm{k} 3$ with 5 concentrations of $1 \%$, $3 \%, 5 \%, 7 \%$ and $9 \%$ for each one was used as aqueous solutions. Each concertation contains three replicates with ten eggs or larva for each replicate. The eggs were sprayed with different solutions while the larvae were fed on the sugar cane pieces after being dipped in the solutions for 20 seconds. The results of statistical analysis showed superiority the plant oils from orange and lemon showed remarkable mortality $(\mathrm{p} \leq 0.05)$ in the number of dead larvae and non-hatched eggs followed by eucalyptus, basil and Castor while other treatments recorded low number of mortalities of larvae and non-hatched eggs. The L.S. D values $(2.49,6.19)$ for eggs and larvae respectively, showed that there were significant differences between oils and significant differences between concentrations. orange and lemon oil showed the strongest effect at $9 \%$ followed by the other concentrations, while k1 and k2 oil had no significant difference with the control at $1 \%$. The study showed that orange and lemon oils as well as eucalyptus, basil and castor can be used in the control of this pest in the stage of the egg and larva.
\end{abstract}

Key words Red palm weevil, Date palm, Plant extracts, Plant oils, Rhynchophorus ferrugineus..

\section{INTRODUCTION}

Date palm (Phoenix dactylifera $\mathrm{L}$.) is one of the key plants dry in semidry regions (Chao and Krueger, 2007). it represents a national wealth in Egypt, where Egypt leads the world in the production of dates equivalent to $18 \%$ of global production of dates in 2018 (FAO 2019).

*Corresponding author: Mahmoud A. Ali, Email: m.abbas@agr.svu.edu.eg

Received: November 9, 2019;

Accepted: December 7, 2019;

Published: December 9, 2019.
The annual production of Egypt is estimated at 1.5 million tons, equivalent to 17.7 percent of world production estimated at 7.5 million tons.

Red palm weevil (RPW) Rhynchophorus ferrugineus Olivier (Coleoptera: Curculionidae) is the most dangerous insect pest of date palm ever seen in Egypt. it was first recorded in date palm plantations of Ismailia Governorate in the early 1990s of the $20^{\text {th }}$ century, (Saleh 1992).

RPW has become widespread due to weak quarantine procedures and the transfer of agricultural products among governorates and the ability of the insect to fly and adapt to environmental conditions throughout the country. 
The insect has a complete metamorphoses life cycle, the eggs are placed individually on the places of pruning and wounds in the palm, Eggs hatched into larvae, which are considered harmful stage, where, they feed on the contents of the trunk of the palm, leaving tunnels to reach the head area of tree and lead to the death of the palm in the end.

Many methods and materials have been developed and used in the management and control of this insect, including the use of pesticides (Llácer et al. 2010), cultural and sanitary control, (Azam and Razvi, 2001) pheromone traps. (Vidyasagar et al. 2000), Sterile insect technique (Ramachandran,1991), and biological control (Falerio, 2006).

The development of new eco-friendly and effective methods and materials towards this pest is urgent and necessary to reduce dependence on hazardous chemical pesticides and maintain the natural balance and beneficial organisms as well as the preservation of human health. Therefore, this study is conducted with the aim of testing and evaluating some plant extracts and oils for control of eggs and larvae.

\section{Materials and Methods}

\subsection{Insect rearing}

To start a culture of the red palm weevil, larvae, pupae and adult of red palm weevil were collected from infested palm trees from the farm of the Faculty of Agriculture, South Valley University, Qena, Egypt at the end of 2017

Adult of red palm weevil were sexually between "differentiated reared" in an oblongate trans- parent plastic boxes (20x $10 \times 15 \mathrm{~cm}$ ) with easily removable perforated covers and fed on small pieces of sugar cane, each box has a pair of males and a pair of adult females.

\subsection{Experimental design}

The present study was conducted in the entomology research lab of plant protection department of the Faculty of Agriculture, South Valley University, Qena, Egypt. A total of one 240 eggs and 240 of the first instar larvae were used in current experiments in completely randomize design.

\subsection{Tested oils}

Five different types of commercial oils and three mixtures were tested: orange oil (Citrus sinensis), lemon oil(Citrus limon L), eucalyptus oil (E. globulus), castor oil(Ricinus communis), basil oil(Ocimum basilicum L.), mixtures of chilli(Capsicum frutescens $\mathrm{L})+$ thyme (Thymus vulgaris) + lavender(Lavandula angustifolia) $=\mathrm{k} 1$, mixture of Colocynth (Citrullus colocynthis) and neem (Azadirachta indica) $=$ k2, mixture of Radicchio (Cichorium intybus var. foliosum Endive) + turmeric(Curcuma longa) + Silene (Silene multinervia) $=\mathrm{k} 3$. The oils were mixed in vitro, in close proportions, using twins $80 \%$ and homogenizer.

\subsection{Concentrations preparation}

concentrations were made for all oils starting from $1 \%, 3 \%, 5 \%, 7 \%$ and $9 \%$ concentrations using distilled water with $80 \%$ Tween at $1 \mathrm{ml} / 100 \mathrm{ml}$ of emulsion. The resulting emulsions were treated with a homogenizer to improve homogeneity.

\subsection{Bioassay for eggs}

Eggs: each concentration contain 30 eggs, which were divided to three replicates, every 10 eggs putted in $10 \mathrm{~cm}$ Petri dish contain a filter paper in bottom and sprayed with $3 \mathrm{ml}$ of previous concentrations of the emulsions.

\subsection{Bioassay for antifeedant activity}

for larvae experiment, fresh and cleaned 7 $\mathrm{cm}$ long pieces of sugarcane stem was treated by dipping in the $10 \mathrm{ml}$ working emulsions 
of the essential oils (EOs) for 20 seconds and then air-dried, whereas control included only emulsifier (Twin 80), and water. two treated sugarcane pieces was placed $10 \mathrm{~cm}$ Petri dish, ten of the $1^{\text {st }}$ instar larvae ( $\mathrm{n}=30 /$ treatment, $\mathrm{r}=3 * 10$ ) were fed on these sugar peace's.

\subsection{Statistical analysis of data}

The statistical analysis was performed using a completely randomized design ,where the Percentages of the hatched eggs and larval mortalities were observed during the eggs and larval period after one, three five and seven days after treatment, also morphological changes were recorded, data analyzed using SPSS for significant among emulsions and concentrations and Duncan multiple range test was used to compare means (Duncan,1955). Significance was declared at $\mathrm{P}<0.05$; P-values. L.D.P. Line software were used to calculate the $\mathrm{LC}_{50}$ values.

\section{Results:}

\subsection{Effects of oils on eggs hatching:}

The insecticidal potential of all tested oils against red palm weevil eggs, as shown in (Table 1,2) and (Fig. 1). In the current study, orange and lemon (Fig. 1) was found to be the most toxic oils against red palm weevil eggs, followed by eucalyptus, basil, and castor, the results of statistical analysis and comparison among the mean treatments of different oils showed significant differences at 5\% level, $(\mathrm{F}=315.118 ; \mathrm{p}<0.000)$ with different concentrations. In contrast, LSD value for the tested oils (Table 1) showed the difference between concentrations with the superiority of orange and lemon at 9\% concentration on other concentrations.

Table 1:ANOVA test values and the least significant difference (LSD) among the tested oils against eggs.

\begin{tabular}{|c|c|c|c|c|c|}
\hline \multicolumn{3}{|c|}{ Subset for alpha $=0.05$} & \multirow{2}{*}{ LSD0.5 } & \multirow{2}{*}{ F 0.05} & \multirow{2}{*}{$\mathrm{P}$ value } \\
\hline Oils & Duncan a & Sig. & & & \\
\hline Lemon & $27.3333^{\mathrm{a}}$ & \multirow{3}{*}{.081} & \multirow{9}{*}{2.49} & \multirow{9}{*}{315.118} & \multirow{9}{*}{$0.00 *$} \\
\hline Orange & $26.6667^{\mathrm{a}}$ & & & & \\
\hline Eucalyptus & $26.0000 \mathrm{a}$ & & & & \\
\hline Castor & $25.6667^{\mathrm{b}}$ & \multirow{2}{*}{.196} & & & \\
\hline Basil & $25.6667^{\mathrm{b}}$ & & & & \\
\hline $\mathrm{K} 2$ & $24.6667^{\mathrm{c}}$ & \multirow{2}{*}{.095} & & & \\
\hline K1 & $24.6667^{\mathrm{c}}$ & & & & \\
\hline K3 & $24.3333^{d}$ & .095 & & & \\
\hline Control & $.0000^{\mathrm{e}}$ & 1.000 & & & \\
\hline
\end{tabular}


Table 2: $\mathrm{LC}_{50}$ and $\mathrm{LC}_{90}$ values for eight plant oils tested against eggs of red palm weevil.

\begin{tabular}{|c|c|c|c|c|}
\hline \multirow{2}{*}{ No } & \multirow{2}{*}{ Plant oils } & \multicolumn{3}{|c|}{ Mean } \\
\hline & & $\mathrm{LC}_{50} \mathrm{ml} / 100 \mathrm{ml}$ & $\mathrm{LC}_{90} \mathrm{ml} / 100 \mathrm{ml}$ & Slope +/- \\
\hline 1 & Orange & 3.53 & 30.653 & $1.365 \pm 0.328$ \\
\hline r & Lemon & 4.376 & 19.174 & $1.997 \pm 0.374$ \\
\hline r & Basil & 5.363 & 38.028 & $1.507 \pm 0.351$ \\
\hline$\varepsilon$ & Eucalyptus & 5.61 & 84.458 & $1.088 \pm 0.328$ \\
\hline o & Castor & 6.569 & 66.161 & $1.278 \pm 0.345$ \\
\hline 7 & K1 & 7.889 & 71.021 & $1.343 \pm 0.36$ \\
\hline v & $\mathrm{K} 2$ & 8.652 & 41.668 & $1.877 \pm 0.693$ \\
\hline 8 & $\mathrm{~K} 3$ & 9.272 & 137.653 & 1.514 \\
\hline
\end{tabular}

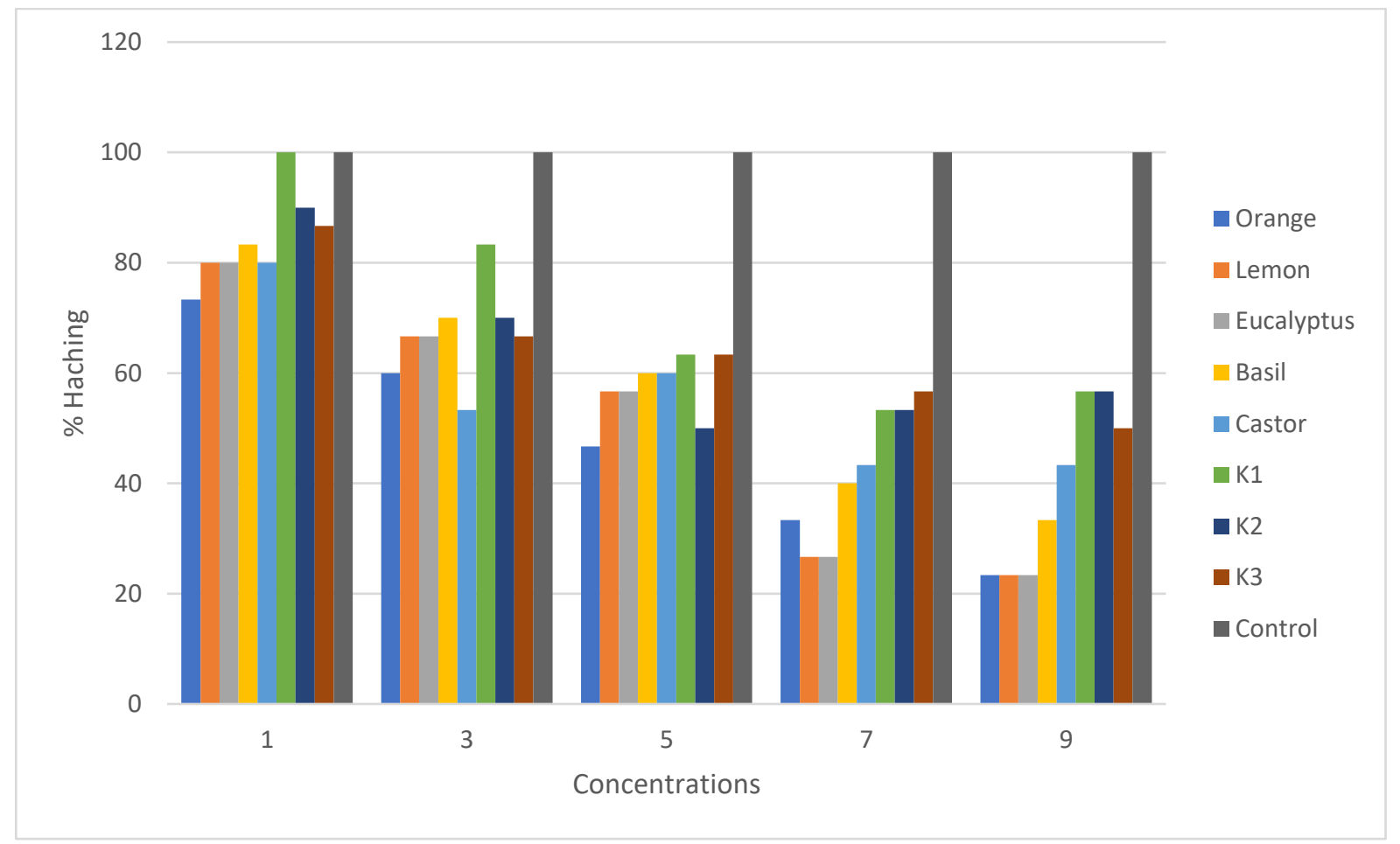

Fig. 1: Comparison of the effect of plant oils on hatching eggs of the red palm weevil. 


\subsection{Effects of oils on larvae:}

The results of statistical analysis (Table3) showed significant differences among the different oils and, and between oils and control, $\mathrm{F}_{.05}=96.446 ; \mathrm{p}<0.000^{*}$ ), while there were no significant differences between both basil and eucalyptus as well as between $\mathrm{K} 1, \mathrm{~K} 2$ and $\mathrm{K} 3$. (LSD=6.19).

Data in (Table 4) and (Fig. 2) reveled that oranges showed the highest toxicity, followed by tangerines that orange was the highest toxic to the larvae $\left(\mathrm{LC}_{50}=2.068\right.$ $\mathrm{ml} / 100 \mathrm{ml})$, followed by lemon oil $\left(\mathrm{LC}_{50}=29.67\right)$ and then Basil and Eucalyptus $\left(\mathrm{LC}_{50}=26.33\right.$ and $25.66 \mathrm{ml} / 100 \mathrm{ml}$ ) respectively. The relatively low values of slope functions revealed the homogenous response of the tested larvae to the different concentrations of the tested oils.

Similarly, (Fig. 2)shows the superiority of orange oil against larvae, followed by tangerines, basil oil, eucalyptus and castor oil

Table 3:ANOVA test values and the least significant difference (LSD) among the tested oils against larvae.

\begin{tabular}{|c|c|c|c|c|c|}
\hline \multicolumn{3}{|c|}{ Subset for alpha $=0.05$} & \multirow{2}{*}{$\mathrm{LSD}_{0.5}$} & \multirow{2}{*}{$\mathrm{F}_{0.05}$} & \multirow{2}{*}{$\mathrm{P}$ value } \\
\hline Oils & Duncan $^{\mathrm{a}}$ & Sig. & & & \\
\hline Orange & 年 & 1 & & & \\
\hline Lemon & $r q, 7 \vee b$ & 1 & & & \\
\hline Basil & ז & .707 & & & \\
\hline Eucalyptus & ro, Trc & & & & \\
\hline Castor & $22.33^{\mathrm{d}}$ & 1 & 7.19 & $97, \leq \leqslant 7$ & $0.00 *$ \\
\hline $\mathrm{K}^{\mu}$ & (17, 17, & & & & \\
\hline K1 & $1 \leqslant, \ldots e$ & .103 & & & \\
\hline$K^{r}$ & $1 \%$, TVe & & & & \\
\hline Control & $.0000^{\mathrm{e}}$ & 1.000 & & & \\
\hline
\end{tabular}


Table 4: $\mathrm{LC}_{50}, \mathrm{LC}_{90}$ values for eight plant oils tested against the $1^{\text {st }}$ instar larvae of red palm

\begin{tabular}{ccccc}
\hline \multirow{2}{*}{ No } & Plant oils & \multicolumn{3}{c}{ Mean } \\
\cline { 3 - 5 }$r$ & orange & LC $50 \mathrm{ml} / 100 \mathrm{ml}$ & LC90 $\mathrm{ml} / 100 \mathrm{ml}$ & Slope $+/-$ \\
\hline$r$ & lemon & 2.068 & 11.982 & $1.68 \pm 0.335$ \\
$r$ & Basil & 3.184 & 19.203 & $1.485 \pm 0.328$ \\
$\varepsilon$ & Eucalyptus & 3.281 & 14.27 & $1.967 \pm 0.325$ \\
0 & Castor & 4.265 & 21.117 & $1.585 \pm 0.336$ \\
$r$ & K1 & 10.181 & 17.43 & $2.096 \pm 0.38$ \\
$V$ & K2 & 11.24 & 48.089 & $1.901 \pm 0.474$ \\
8 & K3 & 11.976 & 129.081 & $1.209 \pm 0.368$ \\
\hline
\end{tabular}

weevil.

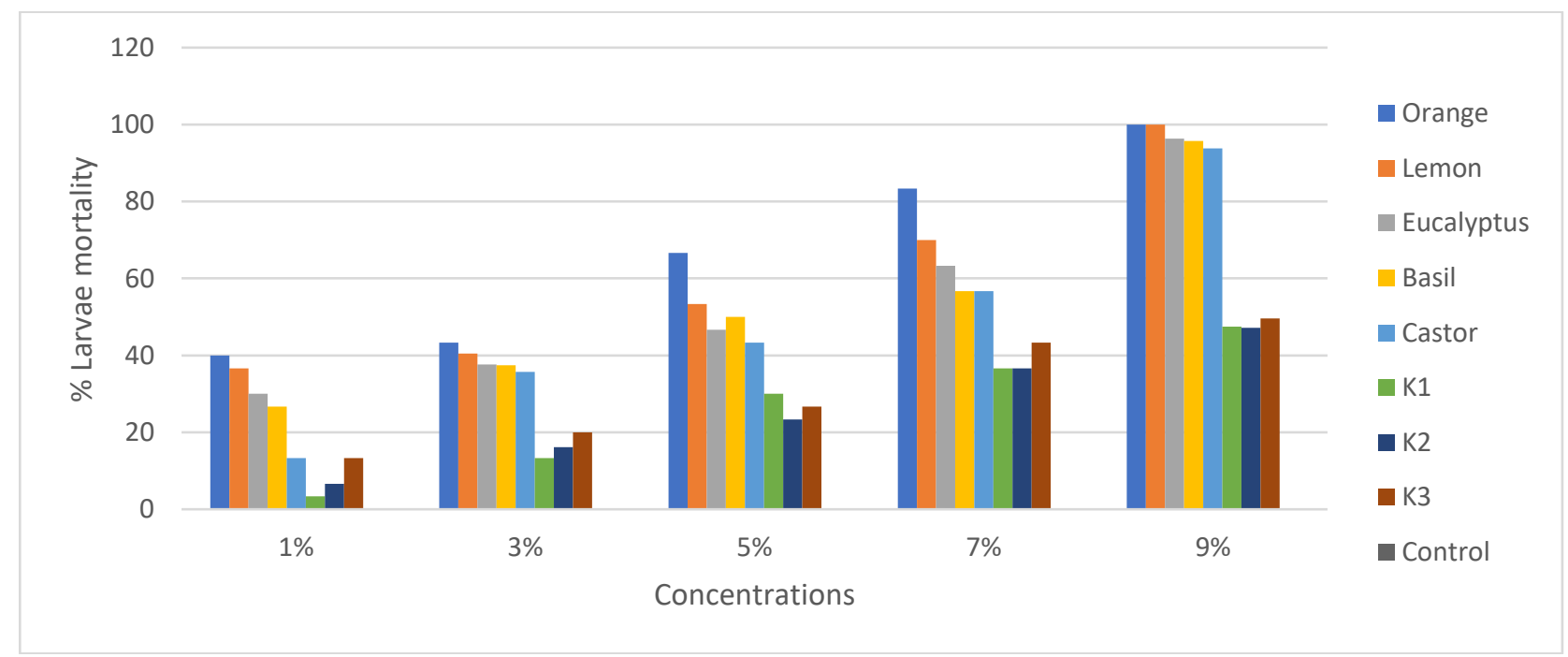

Fig. 2: Toxicity of eight plant oils as surface antifeeding against the $1^{\text {st }}$ instar larva of the red palm weevil.

\section{Discussion}

To overcome insecticide resistance, it requires exploration of the latest, plant-based and eco-friendly pesticides to control the outbreak of Red Palm Weevil. Our current study aims to evaluate some of the diffuse, cheap and eco-friendly plant oils, to reduce the hatching rates of eggs, as well as killing 
larvae of red palm weevil and find the most toxic oils against red palm weevils.

Lower eggs hatching of red palm weevils was recorded from both orange, lemon and eucalyptus. The exposed red palm weevil eggs failed to hatch, especially with the highest concentrations. Furthermore, treated eggs became black or pale in color and these hatched gave sluggish larvae.

The toxic effects of used oils are due to their main components such as monoterpenes, where it seems cause symptoms that suggested to be a neurotoxic mode of action (Kostyukovsky et al., 2002). Disrupting the action of octopamine leads to the complete collapse of the nervous system in insects. so, an octopaminergic system of insects' pests is a vital target for insects' control. It has been demonstrated effect on octopaminergic system of insects. eugenol mimicked octopamine work in increasing intracellular calcium levels in cloned cells from the brain, also this found to be mediated via octopamine receptors (Enan et al., 1998). eugenol induced cellular changes, this are responsible for its insecticidal properties (Price and Berry, 2006). Kosal the repellent action of the tested oils was largely in the vapour phase via respiratory system, or by interact the molecules with receptors, thereby blocking the sense of smell.

Many studies showed that the Citrus EOs oils have insecticidal activity against a wide range of insect pests, it repels target pests rather than killing them. It works by masking scents that are attractive to insects. Thus, insects find it difficult to locate their target to feed. Ibrahim, M., et al. (2001) reported that Limonene is used as an insecticide to control ectoparasites of pet animals, but it has activity against many insects, mites, and microorganisms. Possible attractive effects of limonene to natural enemies of pests may offer novel applications to use natural compounds for manipulation of beneficial animals in organic agriculture The d-Limonene, active ingredients present in the essential oil destroy the wax layer of the insect respiratory system so that once applied directly (Hebeish, A. 2008). Limonene is a cyclic terpene with synonyms (+)-p-mentha-1,8-diene, $\quad(+)$ carvene, and (R)-4-isopropenyl-1-methyl-1cyclohexane. It is one of the main components of essential oil from orange, Citrus sinensis (Osbeck), lemongrass, Cymbopogon citratus (D.C.) Stapf., and Japanese pepper, Zanthoxylum piperitum D.C. (Hieu et al. 2010).

Orange oil has been found to participate in resistance of citrus fruits against the infestation of the Mediterranean fruit fly, Ceratitis capitata (Papachristos et al. 2009), and disease vector pests (Kimbaris et al. 2010).

Citrus EOs oils have an insecticidal activity as a fumigant and contact insecticidal properties against a high range of stored product and agricultural pests (Don-Pedro 1996; Hollingsworth 2005). Vendan, S.E., (2017) showed that, though D-limonene was a major compound in orange $(93 \%)$ and lemon $(66 \%)$ oil, orange and lemon oils offered moderate toxicities on $S$. oryzae attributed by the presence of Dlimonene and $\alpha$-pinene monoterpenoid compounds. he suggests that peppermint and lemon oils can be considered as safer alternatives for commodity treatments. also, Jayakumar, M., et al (2017) recorded the repellent activity of camphor, citronella, eucalyptus, lemon and wintergreen oil essential oils against stored product pests; the adult rice weevil $S$. oryzae due to essential oils components repellent nor attractant activity. Citronella strong, distinctive odour makes it difficult for some pests to locate a host. (BPDB.2019)

Sri Mursiti et al (2019) concluded that dLimonene compounds from sweet orange peel had an activity to control the bedbugs. Anti-flea activity test by using force-feed method indicates more than $50 \%$ dead blight and showed that orange peel extract (Citrus Sinensis L.) can be used as a natural insecticide for bed bug controller (Cimex Cimicidae). 
The pesticidal activity of eucalyptus oils has been due to the components such as monoterpenes (1,8-p-cymene, citronellol, citronellal, limonene, $\alpha$-pinene, $\beta$ phellandrene, $\alpha$-phellandrene, $\quad \beta$-pinene, trans- inocarveol, terpinolene, $\alpha$-thujene, $\alpha$ terpineol) and sesquiterpenes ( $\beta$ caryophyllene, $\beta$ - globulol, eudesmol, spathulenol and virdiflorol (Liu et al., 2008). $\mathrm{Re}$ et al., (2000) demonstrated a monoterpenoid, linalool to act mainly on the nervous system of insects, affecting ion transport and the release of acetylcholine esterase in insects .

Hummel and Isman (2001) showed that Eucalyptus globule is among the most active oils against insects.E. globulus essential oil has high insecticidal activity against Aedes aegypti larvae Lucia et al. (2007). Aphis gossypii (Mareggiani 2008). Terpinen-4-ol; 1,8-cineol; verbenone and camphorin Eucalyptus oil were active against $A$. obtectus adults (Tholl, 2006), insecticidal, and antifeedant against biting insects, (Singh, Kohli, \& Kaur,2008; Bakkali, Averbeck, Averbeck, \& Idaomar, 2008).

also has high insecticidal activity against the pupa of the peach fruit flies (Ali, 2018). Saad, M., (2017) results revealed that essential oils ( $S$. aromaticum) have the highest oviposition deterrent activity followed by $C$. eucalyptusa and $c v$. citratus oils (at $15 \%$ concentration) so it can be included as an integral part of an IPM program against the date palm weevil)

Basil, Ocimum basilicum L. (Lamiales: Lamiaceae), EOs have been exclusively tested against a range of insects and mite pests of crops and stored products, exhibiting contact and fumigant toxicity that affects the development and behavior of insect pests (Papachristos and Stamopoulos 2002; Refaat et al. 2002; Pascual-Villalobos and Ballesta-Acosta 2003; Yi et al. 2006; Kostić et al. 2008; ling Chang et al. 2009) . Eugenol which the principle compound of the essential oils from basil oil have a strong repellent, where eugenol mimicked octopamine in increasing intracellular calcium levels in cloned cells from the brain effect on mosquitoes and linalool also in basil oil has toxic effect to the Bruchid zabrotes sub fasciatus and other storage pests (Chogo \& Crank, 2004; Weaver, D.K., etal (1991). similarly, Kim, Soon-Il, Lee, DaeWeon (2014) reported that basil oil, orange oil, and their components could be potential candidates as new fumigants for the control of S. zeamais and T. castaneum adult. While, findings of Ali (2018) showed that castor oils have active toxicity against pupa of thae peach fruit flies.

\section{Conclusion}

From the previous data, it was clear that, Of the oils used, orange oil, lemon oil, eucalyptus oil, basil and castor oils showed strong toxicity against eggs. And highest antecedent activity against larvae, these oils could be promising active materials used as ecofriendly pesticides for controlling red palm weevil in both eggs and larvae stages It also cannot rely on mixtures in control program.

\section{Acknowledgements}

Financial support provided by Research Management Fund of South Valley University, Egypt is gratefully acknowledged.

\section{Conflict of interest}

The authors hereby declare that no competing and conflict of interests exist.

\section{References}

Ali, M.A. (2018) 'Toxicity of certain plant oils on pupil stage of the peach fruit fly, $B$. zonata (sunders)(Tephritidae: Diptera)', Adv Plants Agric Res, 8(6), pp. 372-374. 
Azam, K.M. and Razvi, S.A. (2001) 'Infestation of red palm weevil, Rhynchophorus ferrugineus in relation to off-shoots on date palm trunk and its management. Paper presented in the meeting on the Red Palm Weevil Rhynchophorus ferrugineus', Muscat, Oman, 19-20 February 2000 (abstract)

Bakkali, F., Averbeck, S., Averbeck, D. and Idaomar, M. (2008) 'Biological effects of essential oils-a review', Food Chem. Toxicol. 46, pp. 446-475

Batish, D.R., Singh, H.P., Kohli, R.K. and Kaur, S. (2008) 'Eucalyptus essential oil as a natural pesticide', Forest Ecology and Management, 256(12), pp. 2166-2174.

BPDB. (2019) 'Bio-Pesticides Database https://sitem.herts.ac.uk/aeru/bpdb/Repo rts/1463.htm(accessed on 20/11/2019).

Chao, C.T. and Krueger, R.R. (2007) 'The date palm (Phoenix dactylifera L.): overview of biology, uses, and cultivation', HortScience, 42(5), pp. 1077-1082.

Choi, W.I., Lee, S.G., Park, H.M. and Ahn, Y.J. (2004) 'Toxicity of plant essential oils to Tetranychus urticae (Acari: Tetranychidae) and Phytoseiulus persimilis Acari:Phytoseiidae)', Journal of economic entomology, 97(2), pp.553-558.

Duncan, DB. (1955) 'Multiple ranges and multiple T-test', Biometrics, 11, pp. 142

Don-Pedro, K.N., 1996. Fumigant toxicity of citruspeel oils against adult and immature stages of storage insect pests', Pesticide Science, 47(3), pp. 213-223.

Enan, E.E. (1998) 'Insecticidal action of terpenes and phenols to the cockroaches: effect on octopamine receptors', In International Symposium on Crop Protection, Gent, Belgium, 1998.
Faleiro, JR. (2006) 'A review of the issues and management of the red palm weevil Rhynchophorus ferrugineus (Coleoptera: Rhynchophoridae) in coconut and date palm during the last one hundred years', International Journal of Tropical Insect Science, 26(3), pp. 135-154.

FAO. (2019) 'Data for Crop Production in 2017',http://www.fao.org/faostat/en/\#da ta (accessed on 25/1/2019).

Hebeish, A., Fouda, M.M., Hamdy, I.A., ElSawy, S.M. and Abdel-Mohdy, F.A. (2008) 'Preparation of durable insect repellent cotton fabric: Limonene as insecticide', Carbohydrate Polymers, 74(2), pp.268-273.

Hieu, T. T., S. I. Kim, H. W. Kwon, and Y. J. Ahn. (2010) 'Enhanced repellency of binary mixtures of Zanthoxylum piperitum pericarp steam distillate or Zanthoxylum armatum seed oil constituents and Calophyllum inophyllumnut oil and their aerosols to Stomoxys calcitrans', Pest Manag. Sci. 66, pp.1191-1198.

Hollingsworth, R. G. (2005) 'Limonene, a citrus extract, for control of mealybugs and scale insects', J. Econ. Entomol. 98, pp.772-779.

Hummelbrunner, L.A. and Isman, M.B. (2001) 'Acute, sublethal, antifeedant, and synergistic effects of monoterpenoid essential oil compounds on the tobacco cutworm, Spodoptera litura (Lep., Noctuidae)', Journal of Agricultural and Food Chemistry, 49(2), pp.715-720.

Ibrahim, M., Kainulainen, P., and Aflatuni, A. (2001) 'Insecticidal, repellent, antimicrobial activity and phytotoxicity of essential oils: With special reference to limonene and its suitability for control of insect pests', Agricultural and Food Science, 10(3), pp. 243-259. doi: 10.23986/afsci.5697 
Jayakumar, M., Arivoli, S., Raveen, R. and Tennyson, S. (2017) 'Repellent activity and fumigant toxicity of a few plant oils against the adult rice weevil Sitophilus oryzae Linnaeus 1763 (Coleoptera: Curculionidae)', Journal of Entomology and Zoology Studies, 5(2), pp.324-335.

Kim, S.I. and Lee, D.W. (2014) 'Toxicity of basil and orange essential oils and their components against two coleopteran stored products insect pests', Journal of Asia-Pacific Entomology, 17(1), pp.1317.

Kimbaris, A.C., Papachristos, D.P., Michaelakis, A., Martinou, A.F. and Polissiou, M.G. (2010) 'Toxicity of plant essential oil vapours to aphid pests and their coccinellid predators', Biocontrol science and technology, 20(4), pp.411-422.

Kostić, M., Popović, Z., Brkić, D., Milanović, S., Sivčev, I. and Stanković, S. (2008) 'Larvicidal and antifeedant activity of some plant-derived compounds to Lymantria disparL.(Lepidoptera:Limantriidae)',

Bioresource Technology, 99(16), pp.7897-7901.

Kostyukovsky, M., Rafaeli, A., Gileadi, C., Demchenko, N. and Shaaya, E. (2002) 'Activation of octopaminergic receptors by essential oil constituents isolated from aromatic plants: possible mode of action against insect pests', Pest Management Science: formerly Pesticide Science, 58(11), pp. 11011106.

Ling Chang, C., Kyu Cho, I. and Li, Q.X., (2009) 'Insecticidal activity of basil oil, trans-anethole, estragole, and linalool to adult fruit flies of Ceratitis capitata, Bactrocera dorsalis, and Bactrocera cucurbitae', Journal of economic entomology, 102(1), pp. 203-209.

Liu, X., Chen, Q., Wang, Z., Xie, L. and Xu, Z. (2008) 'Allelopathic effects of essential oil from Eucalyptus grandis $\times$
E. urophylla on pathogenic fungi and pest insects', Frontiers of Forestry in China, 3(2), pp.232-236.

Llácer, E., Dembilio, O. and Jacas, J.A. (2010) 'Evaluation of the efficacy of an insecticidal paint based on chlorpyrifos and pyriproxyfen in a microencapsulated formulation against Rhynchophorus ferrugineus (Coleoptera: Curculionidae) ', Journal of Economic Entomology, 103(2), pp.402-408.

Lucia, A., Audino, P.G., Seccacini, E., Licastro, S., Zerba, E. and Masuh, H. (2007) 'Larvicidal effect of Eucalyptus grandis essential oil and turpentine and their major components on Aedes aegypti larvae', Journal of the American Mosquito Control Association, 23(3), pp.299-303.

Mareggiani, G.R.A.C.I.E.L.A., Russo, S.E.R.A.F.I.N.A. and Rocca, M.A.R.G.A.R.I.T.A. (2008) 'Eucalyptus globulus (Mirtaceae) essential oil: efficacy against Aphis gossypii (Hemiptera: Aphididae), an agricultural pest' Rev Latinoamer Quím, 36, pp.1621.

Mursiti, S., Lestari, N.A., Febriana, Z., Rosanti, Y.M. and Ningsih, T.W., (2019) 'The Activity of D-Limonene from Sweet Orange Peel (Citrus Sinensis L.) Exctract as a Natural Insecticide Controller of Bedbugs (Cimex cimicidae)', Oriental Journal of Chemistry, 35(4), pp.1420-1425.

Papachristos, D.P., Kimbaris, A.C., Papadopoulos, N.T. and Polissiou, M.G. (2009) 'Toxicity of citrus essential oils against Ceratitis capitata (Diptera: Tephritidae) larvae', Annals of Applied Biology, 155(3), pp.381-389.

Papachristos, D.P. and Stamopoulos, D.C. (2002) 'Repellent, toxic and reproduction inhibitory effects of essential oil vapours on Acanthoscelides obtectus (Say)(Coleoptera: Bruchidae)', 
Journal of stored products research, 38(2), pp.117-128.

Pascual-Villalobos, M.J. and BallestaAcosta, M.C. (2003) 'Chemical variation in an Ocimum basilicum germplasm collection and activity of the essential oils on Callosobruchus maculatus', Biochemical Systematics and Ecology, 31(7), pp. 673-679.

Price, D.N. and Berry, M.S. (2006) 'Comparison of effects of octopamine and insecticidal essential oils on activity in the nerve cord, foregut, and dorsal unpaired median neurons of cockroaches', Journal of insect physiology, 52(3), pp.309-319.

Ramachandran CP. (1991) 'Effects of gamma radiation on various stages of red palm weevil, Rhynchophorus ferrugineus $\mathrm{F}^{\prime}$ Journal of Nuclear Agriculture and Biology, 20(3), pp. 218-221.

Refaat, M., Momen, F.M. and Amer, S.A.A., (2002) 'Acaricidal activity of sweet basil and French lavender essential oils against two species of mites of the family Tetranychidae (Acari: Tetranychidae)', Acta phytopathologica et entomologica hungarica,37(1-3), pp.287-298.

Re, L., Barocci, S., Sonnino, S., Mencarelli, A., Vivani, C., Paolucci, G., Scarpantonio, A., Rinaldi, L. and Mosca, E. (2000) 'Linalool modifies the nicotinic receptor-ion channel kinetics at the mouse neuromuscular junction', Pharmacological Research, 42(2), pp.177-181.

Saad, M.M. (2017) 'Oviposition deterrent effect of four essential oils against the date palm weevil, Rhynchophorus ferrugineus Olivier', Middle East $J, 6(4)$, pp. 1336-1345.
Saleh, M.R.A. (199) 'Red palm weevil, Rhynchophorus ferruginous (Oliver) in the first record for Egypt and indeed the African continent list No: 10634 Africa collection No', International Institute of Entomology., 56Queen5 gate. London, Sw., 75 JR.UK.

Tholl, D. (2006) 'Terpene synthases and the regulation, diversity and biological roles of terpene metabolism', Current opinion in plant biology, 9(3), pp.297-304.

Vendan, S.E., Manivannan, S., Sunny, A.M. and Murugesan, R. (2017) 'Phytochemical residue profiles in rice grains fumigated with essential oils for the control of rice weevil', PloS one, 12(10), p. e0186020.

Vidyasagar, P.S.P.V., Hagi, M., Abozuhairah, R.A., Al Mohanna, O.E. and Al Saihati, A.A. (2000) 'Impact of mass pheromone trapping on red palm weevil: adult population and infestation level in date palm gardens of Saudi Arabia', $\quad$ Planter, Kuala Lumpur, 76(891), pp. 347-355.

Weaver, D.K., Dunkel, F.V., Ntezurubanza, L., Jackson, L.L. and Stock, D.T. (1991) 'The efficacy of linalool, a major component of freshly-milled Ocimum canum Sims (Lamiaceae), for protection against postharvest damage by certain stored product Coleoptera', Journal of Stored Products Research,27(4), pp. 213-220.

Yi, C.G., Choi, B.R., Park, H.M., Park, C.G. and Ahn, Y.J. (2006) 'Fumigant toxicity of plant essential oils to Thrips palmi (Thysanoptera: Thripidae) and Orius strigicollis(Heteroptera:Anthocoridae)', Journal of Economic Entomology, 99(5), pp.1733-1738. 